\title{
Antioxidant, anti-inflammatory, and anti-hyperlipidemic properties of the spelt grass juice
}

\author{
1*Tamara Antonic, 'Aleksandra Stefanovic, \\ 'Tamara Gojkovic, 'Sandra Vladimirov, \\ 'Vesna Spasojevic-Kalimanovska, \\ 'Jelena Kotur-Stevuljevic, \\ ${ }^{1}$ Natasa Bogavac-Stanojevic, ${ }^{2 B}$ ranka Bajic \\ ${ }^{1}$ Department of Medical Biochemistry, Faculty of \\ Pharmacy, University of Belgrade, Belgrade, Serbia \\ 2 Specialist internal medicine practice Hematologica, \\ Belgrade, Serbia \\ Corresponding author: \\ Tamara Antonic, MSc \\ Department of Medical Biochemistry, Faculty of \\ Pharmacy, University of Belgrade, Vojvode Stepe 450, \\ P. Box 146, 11000 Belgrade, Serbia \\ Phone/fax: (+381 11) 39-70-265, (+381 11) 39-72-840 \\ E-mail address: tamara.antonic@pharmacy.bg.ac.rs
}

\begin{abstract}
Spelt is a grain rich in bioactive compounds - different phytochemicals, so it is often mentioned in the context of being beneficial to human health. We aimed to investigate the antioxidant, anti-inflammatory, and anti-hyperlipidemic properties of the spelt grass juice. Twenty volunteers consumed a beverage once a day, by dissolving one dose in $200 \mathrm{ml}$ of still water, for 2 months. All individuals were clinically and biochemically examined. The individual profiles of $L D L$ and $H D L$ particles were determined by polyacrylamide gradient gel electrophoresis, while the concentrations of non-cholesterol sterols were measured using the gas chromatography - flame ionization detector. High-sensitivity Creactive protein (hsCRP) was measured using the commercially available kit. Concentrations of oxidative stress status parameters were measured spectrophotometrically. Though no change was observed in lipid profile parameters, values of coronary risk $(C R I)(p<0.05)$ and the atherogenic indexes (AI) $(p<0.05)$ after the supplementation were lower compared with values before the dietary intervention. After analyzing the markers of cholesterol synthesis and absorption, we only noticed a significant in-
\end{abstract} crease in campesterol concentrations $(p<0.05)$. Moreover, we found a statistically significant reduction in $h s C R P$ concentrations in subjects who underwent spelt juice supplementation $(p<0.001)$. A significant decrease in PAB $(p<0.001)$, AOPP $(p<0.05)$ and PON1 $(p<0.001)$ was recorded after supplementation. On the other side, TAS values and concentration of $S H$ groups were significantly higher after the dietary intervention $(p<0.001$, both). We suggested a possible beneficial effect of the spelt grass supplementation on the overall lipid profile, the prooxidant-antioxidant balance, and inflammatory parameters.

Key words: spelt; spelt grass juice; non-cholesterol sterols; phytosterols; prooxidant-antioxidant balance; inflammation.

\section{INTRODUCTION}

Spelt (lat. Triticum aestivum subsp. spelta) shares its genes with the common wheat (lat. Triticum aestivum subsp. vulgaris), which replaced the spelt in everyday use [1]. Namely, spelt is an ancient grain which is mentioned even in the Neolithic period (VI century BC) [2], and in Europe, it was an important staple from $V$ to $X X$ century, when it was replaced by its modern relative bread wheat [1]. Although genetically close, the spelt is physically and biologically significantly different from common wheat [3].

Spelt is characterized by the presence of soluble, easily digestible carbohydrates, and is a significant source of protein and dietary fiber [3]. In addition to dietary fiber, this crop is rich in other bioactive compounds - different phytochemicals, so it is increasingly mentioned in the context of being beneficial to human health [4].

Spelt is suitable for the preparation of various products, such as bread, pasta, and extruded products [3]. The largest number of studies so far dealt with the technological and nutritional characteristics of this grain and its products, such as flour and bread [3,5,6]. In their review article, Biskup et al. [4] considered the potential role of bioactive compounds isolated from spelt in glycemic control and concluded that the polyphenols from spelt may have an important role in maintaining lipid and glucose homeostasis. According 
to Dinu et al. [7] 13 studies comparing the effects of ancient and modern wheat cultivars on human health, have been conducted by now. Interestingly, previously mentioned human trials have shown that products made of ancient wheat species have a beneficial effect on pro-inflammatory and antioxidant parameters, but also on glycemic and lipid profile, which has not been proven for the products made of commercially available cultivars [7]. However, only one of the studies dealt with the benefits of spelt on human health, by examining the possible hypoallergenic effects of this crop in patients with wheat allergy [8].

\section{OBJECTIVE}

Therefore, according to our knowledge, no study investigated the antioxidant and anti-hyperlipidemic effects of spelt. Our study aimed to investigate the antioxidant, anti-inflammatory, and anti-hyperlipidemic properties of the spelt grass juice.

\section{METHODS}

\section{Subjects}

Twenty volunteers aged 25 to 67 were included in our intervention study. Respondents took a beverage once a day, in the morning, by dissolving one dose (one frozen cube of juice) in $200 \mathrm{ml}$ of still water, for 2 months.

All individuals were clinically and biochemically examined; age, sex, blood pressure, and estimated risk factors were collected (including a family history of cardiovascular disease, arterial hypertension, and metabolic disorders, smoking status, medications used, and other socioeconomic variables). The information was collected in person using a standard questionnaire filled out by the trained examiner. Study participants were characterized as hypertensive if their systolic blood pressure was $\geq 140 \mathrm{mmHg}$ and/or diastolic blood pressure $\geq 90 \mathrm{mmHg}$ [9].

The study protocol included the measurement of height and body weight, and the body mass index (BMI) was then calculated according to the formula $\mathrm{BMI}=$ height/weight ${ }^{2}$. Waist and hip circumference were measured, and waist-to-hip ratio (WHR) was calculated to estimate the degree of abdominal obesity. According to the criteria of the World Health Organization (WHO), subjects with $\mathrm{BMI} \leq 25 \mathrm{~kg} / \mathrm{m}^{2}$ were defined as healthy weight, overweight if the BMI was > $25 \mathrm{~kg} / \mathrm{m}^{2}$ and $<30 \mathrm{~kg} / \mathrm{m}^{2}$, and obese if BMI was $\geq 30$ $\mathrm{kg} / \mathrm{m}^{2}$ [10]. To determine the fatty tissue distribution in our subjects, we evaluated their WHRs. Based on the recommendations of $\mathrm{WHO}$, abdominal obesity is diagnosed in women with $\mathrm{WHR} \geq 0.85$, and in men with WHR $\geq 0.90$ [11].

The study was planned and conducted according to the ethical standards of the Helsinki Declaration (as revised in 1983) and institutional guidelines. The study was approved by Ethical Committee of Faculty of Pharmacy, University of Belgrade.

\section{Sample collection}

At both points - before and up to 7 days after supplementation - venous blood samples were taken from subjects after an overnight fast ( $>10 \mathrm{~h}$ ). Samples were collected in sera vacutainers (Becton, Dickinson and Company, New Jersey, United States of America) and after the coagulation process (40 minutes), centrifuged at $1500 \mathrm{~g}$ for 10 minutes at room temperature. Sera samples were aliquoted and stored at $-80^{\circ} \mathrm{C}$ until analysis.

The activity of creatine kinase (CK) was determined to assess the muscle tissue status, while activities of enzymes aspartate aminotransferase (AST) and alanine aminotransferase (ALT) were measured to assess liver status in the study subjects. To estimate the kidney function we measured creatinine and uric acid concentrations, while calcium, magnesium, sodium, potassium, and chloride ion concentrations were determined to check the ionic composition of blood. The activity of CK, AST, ALT, and creatinine, uric acid, calcium, and magnesium concentrations were measured on ILab 300+ analyzer (Instrumentation Laboratory, Milan, Italy) using commercially available kits (Biosystems SA, Barcelona, Spain), while sodium, potassium, and chloride ion analysis were done using ion-selective electrodes on analyzer Dimension RxLmax (Siemens Health Care Diagnostics, Erlangen, Germany) in General Hospital "Sveti Luka", Smederevo, Serbia.

Lipid profile parameters - total cholesterol (TC), high-density lipoprotein cholesterol (HDL-cholesterol; $\mathrm{HDL}-\mathrm{C}$ ), and triglycerides (TG) - were measured on an autoanalyzer (Olympus AU400 Clinical Chemistry Analyzer) using commercially available kits (Biosystems SA, Barcelona, Spain). Low-density lipoprotein cholesterol (LDL-cholesterol; LDL-C) was calculated according to Friedwald's formula: LDL-C = TC - HDL-C - TG/2.22 [12]. Coronary risk index (CRI) was calculated as TC/LDL-C, while the atherogenic index (Al) was calculated using the following formula: $\mathrm{AI}=\mathrm{LDL}-\mathrm{C} / \mathrm{HDL}-\mathrm{C}$ [13]. Further, the individual profile of LDL and HDL particles was determined in all subjects using the previously described method - polyacrylamide gradient (3-31\%) gel electrophoresis [14]. The concentration of non-cholesterol sterols, parameters describing cholesterol synthesis and absorption, were measured using the gas chromatography - flame ionization detector (GC-FID) method previously validated in our laboratory [15]. Saponification was carried out for $1 \mathrm{~h}$ incubation at $67{ }^{\circ} \mathrm{C}$ with ethanol and $\mathrm{KOH}$. The extraction procedure with hexane was repeated three times. After the desalting procedure of organic phases and completely drying the extract, derivatization reagent Sylon ${ }^{\text {TM }}$ HTP (HMDS + 
TMCS + Pyridine, 3:1:9) (Supelco, Bellefonte, PA, USA) was added, followed by $1 \mathrm{~h}$ incubation at $67^{\circ} \mathrm{C}$. Separation of the analytes was done on Agilent HP-5 ((5\% phenyl) - methyl siloxane) non-polar capillary column (30 m x $0.32 \mathrm{~mm} \times 0.25 \mu \mathrm{m}$ ). Desmosterol and lathosterol were used as cholesterol synthesis markers, while campesterol and $\beta$-sitosterol were used to evaluate cholesterol absorption [15]. Highsensitivity C-reactive protein (hs(RP), a marker of inflammation was measured using the commercially available kit (Biosystems SA, Barcelona, Spain).

Total oxidant status (TOS), total antioxidant status (TAS), and prooxidant/antioxidant balance (PAB) were evaluated by modified spectrophotometric methods using o-dianisidine, ABTS, and 3,3', 5,5'-tetramethylbenzidine, respectively; implemented on ILab 300+ analyzer (Instrumentation Laboratory, Milan, Italy). Total protein sulfhydryl ( $\mathrm{SH}-$ ) group content was determined using 5,5'-dithiobis (2-nitrobenzoic acid). Advanced oxidation protein products (AOPP) were quantified in reaction with glacial acetic acid and potassium iodide. All of the methods are described elsewhere [16].

\section{Statistical analysis}

The distribution of data was tested using the Shapiro-Wilk statistical test. The normally distributed data were shown as an arithmetic mean and 95\% confidence intervals and as geometric mean and 95\% confidence interval derived from log-normal values for parameters that followed normal distribution after logarithmic transformation. Parameters that did not follow normal distribution were shown as median and interquartile range. Continuous variables were compared by Paired Samples T-Test if following normal distribution, or by Wilcoxon Signed-Ranks Test for data that are not normally distributed. Categorical variables were analyzed using a binomial test (when only two variables were present) and a chi-square test for homogeneity. Spearman's correlatransferase. tion analysis was used to check for significant correlations between the examined variables. The minimum requirement to define a statistically significant difference was the probability ( $p$, significance level) smaller or equal to 0.05 . Statistical analysis was performed using PASW Statistics 18.

Table 1. Demographic data and general biochemical parameters of subjects included in the study.

\begin{tabular}{|c|c|c|c|}
\hline Parameter & Before & After & $\mathbf{p}$ \\
\hline \multicolumn{4}{|l|}{ Number of subjects } \\
\hline Female & $11(55 \%)$ & & \\
\hline Male & $9(45 \%)$ & & \\
\hline Age (years) & $45 \pm 10.6$ & & \\
\hline BMI $\left(\mathrm{kg} / \mathrm{m}^{2}\right)^{*}$ & $24.9(23.1-26.8)$ & & \\
\hline Category & Number of subjects & & \\
\hline$\leq 25 \mathrm{~kg} / \mathrm{m}^{2}$ & $7 / 14$ & & \\
\hline $25-30 \mathrm{~kg} / \mathrm{m}^{2}$ & $5 / 14$ & & \\
\hline$\geq 30 \mathrm{~kg} / \mathrm{m}^{2}$ & $2 / 14$ & & \\
\hline WHR & $0.86 \pm 0.11$ & & \\
\hline Category & Number of subjects & & \\
\hline$<0.85$ (female) or $<0.90$ (male) & $10 / 14$ & & \\
\hline$\geq 0.85$ (female) or $\geq 0.90$ (male) & $4 / 14$ & & \\
\hline $\mathrm{SBP}(\mathrm{mmHg})$ & $121 \pm 15.8$ & & \\
\hline $\mathrm{DBP}(\mathrm{mmHg})$ & $74 \pm 9.2$ & & \\
\hline $\mathrm{CK}(\mathrm{U} / \mathrm{I})^{\#}$ & $125.5(75.0-185.0)$ & $142.0(98.0-177.0)$ & 0.687 \\
\hline $\mathrm{AST}\left(\mathrm{U} / \mathrm{I}^{\#}\right.$ & $22.5(18.2-26.7)$ & $23.0(21.0-28.0)$ & 0.975 \\
\hline $\operatorname{ALT}(\mathrm{U} / \mathrm{I})^{*}$ & $18.3(13.8-24.1)$ & $18.1(14.7-22.2)$ & 0.666 \\
\hline Creatinine $(\mu \mathrm{mol} / \mathrm{l})^{\#}$ & $98.3(86.0-113.2)$ & $96.0(89.3-103.0)$ & 0.177 \\
\hline Uric acid $(\mu \mathrm{mol} / \mathrm{l})$ & $435.4 \pm 114.58$ & $429.5 \pm 93.78$ & 0.712 \\
\hline Calcium (mmol/l) & $2.3 \pm 0.10$ & $2.3 \pm 0.11$ & 0.090 \\
\hline Magnesium (mmol/l) & $0.85 \pm 0.057$ & $0.83 \pm 0.073$ & 0.325 \\
\hline Sodium $(\mathrm{mmol} / \mathrm{l})^{\#}$ & $141.0(140.0-143.5)$ & $141.0(140.0-142.0)$ & 0.794 \\
\hline Potassium (mmol/l) & $4.5 \pm 0.26$ & $4.5 \pm 0.39$ & 0.865 \\
\hline Chloride $\left(\mathrm{mmol} / \mathrm{II}^{\#}\right.$ & $106.0(105.0-107.7)$ & $105.0(104.0-106.0)$ & 0.071 \\
\hline
\end{tabular}

BMI - body mass index; WHR - waist to hip ratio; SBP - Systolic blood pressure; DBP - diastolic blood pressure; CK - Creatine kinase; AST - Aspartate aminotransferase; ALT - Alanine amino-

Data are shown as mean \pm standard deviation; " geometric mean (95th confidence interval); ${ }^{*}$ median (interquartile range). 


\section{RESULTS}

Demographic data of all subjects included in the intervention study are represented in Table 1. Of a total of 20 subjects, $55 \%$ of them were female and $45 \%$ were male. We showed that the respondents were homogeneously distributed according to gender ( $p=0.842$ ). Subjects aged 25 to 67 were enrolled in the study, and the average age was $45 \pm 10.6$ years (Table 1). In the study conducted, 5 subjects had excessive body weight, while 2 subjects were classified as obese. Abdominal obesity was recognized in 4 out of 14 subjects. Hypertension was observed in 3 of our respondents.

Results of general biochemical parameters before and after supplementation were also presented in Table 1. As expected, no significant changes in the level of previous parameters were observed during the supplementation.

As shown in Table 2, we did not notice a significant change in any of the lipid profile parameters during the supplementation. However, significant differences were found between CRI and Al. Values of CRI $(p<0.05)$ and $\mathrm{Al}(\mathrm{p}<0.05)$ after the supplementation were lower compared with values before the dietary intervention (Table 2). A comparison of LDL and HDL size revealed no significant difference in the dominant diameter of before mentioned lipoprotein particles in subjects before and after supplementation (Table 2). Also, we did not find any significant difference in the relative proportions of different LDL and HDL subtypes' distribution (data not shown).

Table 2. Concentrations of lipid profile parameters and lipoprotein particles size before and after supplementation.

\begin{tabular}{llll}
\hline Parameter & Before & After & p \\
\hline $\begin{array}{l}\text { Cholesterol } \\
\text { (mmol/l) }\end{array}$ & $5.5 \pm 0.52$ & $5.5 \pm 0.45$ & 0.837 \\
$\begin{array}{l}\text { LDL - choles- } \\
\text { terol (mmol/l) } \\
\text { HDL - choles- }\end{array}$ & $3.4 \pm 0.44$ & $3.3 \pm 0.47$ & 0.325 \\
terol (mmol/l) & $1.57 \pm 0.47$ & $1.64 \pm 0.47$ & 0.081 \\
$\begin{array}{l}\text { Triglycerides } \\
\text { (mmol/l) }\end{array}$ & $1.15 \pm 0.49$ & $1.16 \pm 0.49$ & 0.869 \\
CRI & $3.57 \pm 1.003$ & $3.57 \pm 0.929$ & $<\mathbf{0 . 0 5}$ \\
Al & $2.36 \pm 0.773$ & $2.20 \pm 0.756$ & $<\mathbf{0 . 0 5}$ \\
LDL size (nm) & $27.0 \pm 1.44$ & $26.5 \pm 1.26$ & 0.294 \\
HDL size $(\mathrm{nm})^{\#}$ & $9.1(8.6-10.2)$ & $9.8(8.8-10.3)$ & 0.171 \\
\hline
\end{tabular}

$\mathrm{LDL}$ - cholesterol - cholesterol in low-density lipoproteins; $\mathrm{HDL}$ - cholesterol in high-density lipoprotein; CRI - coronary risk index; $\mathrm{Al}$ - atherogenic index.

Data are shown as mean \pm standard deviation; "median (interquartile range).
We also measured concentrations of non-cholesterol sterols, markers of cholesterol synthesis, and absorption in all individuals included in the study. Levels of cholesterol synthesis and absorption markers are represented as both absolute concentrations and corresponding NCS/cholesterol ratios (Table 3). These ratios are used to reduce the possibility of results misinterpretation resulting from interindividual differences in total cholesterol concentrations among subjects.

After analyzing the markers of cholesterol synthesis and absorption, we noticed a significant change in campesterol concentrations ( $p$ 0.05) (Table 3). As expected, campesterol concentrations were higher after the supplementation compared to the values

Table 3. Changes in non-cholesterol sterols concentrations and non-cholesterol sterol/ cholesterol ratios before and after spelt juice supplementation.

\begin{tabular}{llll}
\hline Parameter & Before & After & p \\
\hline Desmosterol $(\mu \mathrm{mol} / \mathrm{l})$ & $10.38(9.32-11.57)$ & $10.30(9.35-11.35)$ & 0.862 \\
$\begin{array}{l}\text { Lathosterol }(\mu \mathrm{mol} / \mathrm{l}) \\
\text { Campesterol }(\mu \mathrm{mol} / \mathrm{l})\end{array}$ & $10.14(8.66-11.86)$ & $9.92(8.13-12.10)$ & 0.808 \\
$\beta$-sitosterol $(\mu \mathrm{mol} / \mathrm{l})$ & $13.95(11.60-16.79)$ & $14.00(12.34-15.88)$ & 0.974 \\
\hline $\begin{array}{l}\text { Desmosterol/cholester- } \\
\text { ol }(\mu \mathrm{mol} / \mathrm{mmol})\end{array}$ & $1.91(1.73-2.11)$ & $1.88(1.71-2.08)$ & 0.803 \\
$\begin{array}{l}\text { Lathosterol/cholesterol } \\
(\mu \mathrm{mol} / \mathrm{mmol})\end{array}$ & $1.86(1.61-2.15)$ & $1.81(1.48-2.22)$ & 0.774 \\
$\begin{array}{l}\text { Campesterol/cholester- } \\
\text { ol }(\mu \mathrm{mol} / \mathrm{mmol})\end{array}$ & $3.45(3.13-3.81)$ & $3.97(3.52-4.47)$ & $<\mathbf{0 . 0 5}$ \\
$\beta$-sitosterol/cholesterol & $2.56(2.17-3.03)$ & $2.56(2.24-2.92)$ & 0.991 \\
\begin{tabular}{l}
$(\mu \mathrm{mol} / \mathrm{mmol})$ \\
\hline
\end{tabular}
\end{tabular}

Data are shown as geometric mean and 95th confidence interval.

measured before the supplementation. A significant difference, i.e., an increase, was also observed after correction of campesterol for total cholesterol concentrations, by calculating the appropriate ratio $(p<0.05)$ (Table 3).

No statistically significant difference in either preor post-supplementation values of other NCSs has been demonstrated (Table 3). Desmosterol concentrations before supplementation were almost identical to the values measured after supplementation $(p=$ 0.862 ) and the desmosterol/cholesterol ratio was also unchanged $(p=0.803)$. Similarly, lathosterol concentrations before supplementation did not differ when compared to values measured after the supplementation $(p=0.808)$. The situation did not change significantly even after calculating the lathosterol/desmosterol ratio $(p=0.774)$.

To find possible associations between non-cholesterol sterols ratios and coronary risk and atherogenic indices, we performed Spearman's correlation analysis. The only significant correlation was observed between lathosterol/campesterol ratios and coronary risk 
indices before (Spearman's $\rho=0.589, p<0.05$ ), as well as after the supplementation process (Spearman's $\rho=$ 0.540, $\mathrm{p}<0.05)$.

From the results obtained, we noticed that $25.0 \%$ of subjects had high hsCRP values indicating high risk for cardiovascular disease development before supplementation, and $70.0 \%$ of them were classified as a group with moderate risk; whereas low concentrations defining low risk of developing some cardiovascular disease were measured in $47.7 \%$ of subjects and only $10.5 \%$ of our subjects had concentrations higher than $3 \mathrm{mg} / \mathrm{l}$ (high risk) after supplementation (Figure 1). The risk for cardiovascular disease development differed in our subjects before and after supplementation ( $p<0.05$ ). Moreover, we found a statistically significant reduction in hsCRP concentrations in subjects who underwent spelt juice supplementation ( $p<0.001$ ) (Figure 2).

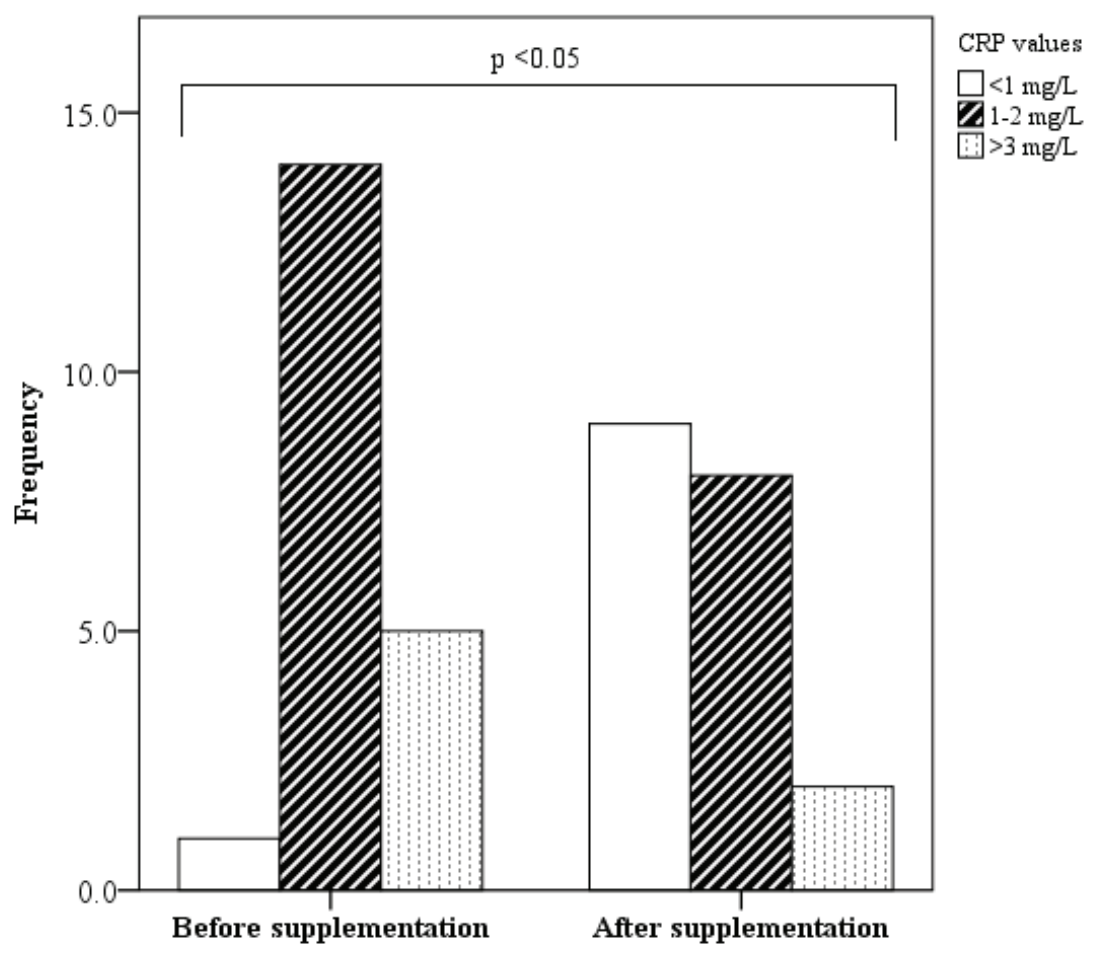

Figure 1. HsCRP values and cardiovascular risk before and after the spelt grass juice supplementation.

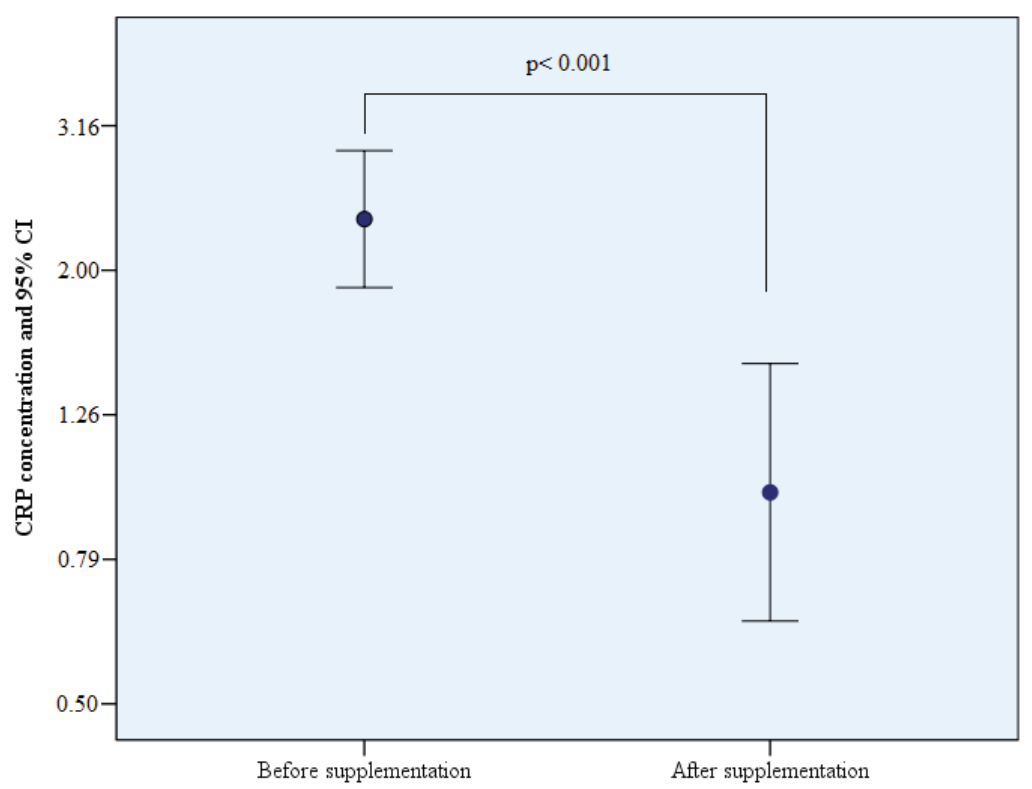

Figure 2. HsCRP values before and after the spelt grass juice supplementation. 
We observed changes in oxidative stress parameters during supplementation (Table 4). Statistically significant differences were noticed for PAB and AOPP values. A significant decrease in $P A B$ values was recorded $(p<0.001)$. A decrease in AOPP concentration during the spelt juice supplementation was also significant ( $p$ $<0.05$ ). We did not find a statistically significant difference in TOS values before and after the supplementation $(p=0.085)$.

In addition to markers of oxidative stress, we investigated antioxidant defense markers also (Table 4). The activity of enzyme paraoxonase 1 was lower after compared to the values before supplementation $(p<$ $0.001)$. However, TAS values were significantly higher after the spelt grass juice supplementation $(p<0.001)$. Likewise, the concentration of SH groups increased ( $p$ $<0.001$ ).

In addition, we observed the relationship between the TAS and TOS parameters by calculating the TAS/ TOS index. There was no statistically significant change in the aforementioned index ( $p=0.231)$; though, the values after supplementation were somewhat higher than those calculated before spelt juice supplementation (Table 4).

Table 4. Oxidative stress and antioxidant protection markers before and after spelt grass juice supplementation.

\begin{tabular}{llll}
\hline Parameter & Before & After & p \\
\hline TOS $(\mu \mathrm{mol} / \mathrm{l})^{\#}$ & $3.9(2.6-4.3)$ & $3.6(2.3-13.4)$ & 0.085 \\
AOPP $(\mu \mathrm{mol} / \mathrm{l})$ & $21.4 \pm 3.54$ & $18.1 \pm 4.54$ & $<\mathbf{0 . 0 5}$ \\
PAB $(\mathrm{U} / \mathrm{l})$ & $68.3 \pm 15.90$ & $58.9 \pm 14.78$ & $<\mathbf{0 . 0 0 1}$ \\
TAS $(\mu \mathrm{mol} / \mathrm{l})$ & $930.6 \pm 149.58$ & $1406.9 \pm 105.55$ & $<\mathbf{0 . 0 0 1}$ \\
PON1 $(\mathrm{U} / \mathrm{l})$ & $720.9 \pm 474.17$ & $552.9 \pm 347.67$ & $<\mathbf{0 . 0 0 1}$ \\
SH groups $(\mathrm{mmol} / \mathrm{l})$ & $0.255 \pm 0.0648$ & $0.331 \pm 0.0479$ & $<\mathbf{0 . 0 0 1}$ \\
TAS/TOS ratio\# & $239.6(187.7-320.9)$ & $382.1(107.2-612.2)$ & 0.231 \\
\hline
\end{tabular}

TOS - Total oxidant status; AOPP - Advanced oxidation protein products; PAB - Prooxidant/antioxidant balance; TAS - total antioxidant status; PON1 - Paraoxonase 1; SH groups - Total protein sulfhydryl groups.

Data are shown as mean \pm standard deviation; "median (interquartile range).
We found no significant adverse effects of spelt grass juice consumption in our subjects. According to the general biochemical parameters spelt grass juice supplementation did not have a significant impact on muscle tissue status, heart, liver, and kidney function (Table 1).

Spelt is a significant source of dietary fibers, plants' structural component from the carbohydrate group, and it has been confirmed that the content of soluble dietary fibers is higher in spelt compared to the common wheat [3]. Given that plant fibers have a high adsorption potential, consumption of spelt grain could lead to a significant reduction in food cholesterol absorption, thereby maintaining optimal cholesterol blood level [18].

Although the changes in lipid profile parameters observed in the study were not statistically significant, there was a marked reduction in coronary risk index as well as in atherogenic index (Table 2). The coronary risk index is used in predicting the morbidity and severity of coronary stenosis [19], while the atherogenic index is a marker predicting cardiovascular risk [20]. Thus, by calculating the appropriate indexes, we noticed that although the changes in concentrations of lipid parameters after supplementation were not statistically significant, taken together they reported the positive effect of spelt juice on the lipid profile of our subjects.

Maintaining cholesterol homeostasis in the body implies a balance between the synthesis and absorption processes. Any disturbance of this balance can lead to dyslipidemia and the consequent development of atherosclerosis [21]. Bearing in mind that approximately one-third of the total cholesterol content in the body is dietary cholesterol, controlling the absorption process could be of utmost importance for maintaining the overall balance of this biomolecule in the

\section{DISCUSSION}

Over the last few years, the principle that food is considered not just as a source of energy and nutrients but that certain food components have a clear health benefit, particularly in the prevention of chronic diseases such as cardiovascular disease, has been established [17]. Besides being a grain with a high nutritional value containing almost all nutritive components necessary in the human diet - highly utilizable carbohydrates, proteins, and lipids, spelt is a significant source of dietary fibers, vitamins, minerals, and different phytochemicals - biologically active compounds $[3,6]$. organism [21]. In addition to fibers, spelt is a significant source of phytosterols, components naturally occurring in raw foods and exhibiting biological activity when introduced into the human body [22]. Several studies have demonstrated that phytosterols, including campesterol and $\beta$-sitosterol, have a beneficial effect on reducing the levels of total and LDL-cholesterol in the circulation [23]. Due to the structural similarity between cholesterol and phytosterols, optimal intake of plant sterols reduces intestinal absorption of cholesterol and leads to a reduction of LDL-cholesterol by 6-15\% [24]. 
Numerous studies have demonstrated the different distribution of phytosterols in cereals, as well as in some anatomic parts of plants (aleuronic layer, endosperm, pericarp, seeds, and germs) [17]. Given that campesterol is one of the most common herbal sterols in Triticum aestivum subsp. spelta, a significant increase in campesterol concentrations after spelt grass juice supplementation was expected (Table 3 ). A significant increase after adjusting campesterol for cholesterol concentrations was also noted, confirming the positive effect of spelt juice supplementation on cholesterol status in an organism.

Due to their structural similarities, phytosterols, including campesterol, lead to a decrease in intestinal cholesterol absorption, thereby lowering the concentrations of total and LDL-cholesterol in plasma [24]. It is expected that these phytochemicals could have significant health benefits, particularly in reducing the risk of cardiovascular disease, as confirmed by the positive correlation between the lathosterol/campesterol ratio and the coronary risk index values found in the study, both before and after the spelt grass juice supplementation.

Though we noticed a decrease in exogenous cholesterol absorption, small changes in the concentration of lipid parameters were not sufficient to result in statistically significant remodeling of lipoprotein particles (data not shown).

Metabolic and inflammatory diseases are two major global health problems for millions of patients today. It has long been known that inflammation is the symptom of many infectious diseases, but new studies indicate that it is closely related to a large number of non-infectious diseases, perhaps even with all [25]. Given that inflammation can play a crucial role in the development of many diseases, suppression of inflammatory processes is an interesting target for many therapeutics as well as biologically active compounds representing the natural food components [25]. Given data provided strong evidence to conclude that the risk for cardiovascular disease development in our subjects was lower after supplementation $(p<0.05)$. Moreover, we found a statistically significant reduction in hsCRP concentrations in subjects who underwent spelt juice supplementation ( $p<0.001$ ), indicating that the spelt grass juice could have protective, anti-inflammatory characteristics (Figure 2).

As observed for wheatgrass juice, the anti-inflammatory properties of spelt grass juice could be attributed to chlorophyll, the bioactive molecule present in green plants [26]. It has been observed that chlorophyll is effective in the treatment of some wounds and that it could support fracture recovery [26]. Subramoniam et al. [27] found that chlorophyll a and pheophytin a, isolated from S. asper have significant anti-inflammatory effects, comparable to those of diclofenac, a wellknown nonsteroidal anti-inflammatory drug (NSAID) [27].
Oxidative stress is a phenomenon implied in the pathogenesis of different diseases. It occurs when free radicals are increased in certain pathological conditions, and when their formation overcomes mechanisms of antioxidant protection, either naturally occurring in our organism or taken from food [28]. Studies on the nutritional composition of wheatgrass subspecies have shown that besides the high chlorophyll and minerals content, these plants are characterized by the presence of antioxidants such as beta-carotene, vita$\min \mathrm{E}$, and vitamin $\mathrm{C}$. In addition, the high antioxidant activity of wheatgrass species is a result of the high content of phenolic components - bioflavonoids, such as apigenin, quercetin, and luteolin [29].

Since spelt is a wheat subspecies and by the previous statements, changes in prooxidant and antioxidant concentrations observed in our study were quite expected (Table 4). Significantly higher concentrations of antioxidants, measured through TAS and $\mathrm{SH}$ group concentrations, and a decrease in PAB values after supplementation, could be attributed to the high content of antioxidants in spelt grass juice. Significantly lower AOPP concentrations could be explained by the high content of bioactive components such as polyphenols, including lignans and bioflavonoids, and chelating agents such as tocochromanols, tocotrienols, and phytic acid, useful in protection against glycoxidation, a process which attributes AOPP formation [4]. Lower activity of paraoxonase 1 could also be the result of high antioxidant content in spelt juice since it was previously suggested that administration of exogenous antioxidants can cause a compensatory deterioration in endogenous antioxidant defense systems [30].

\section{CONCLUSION}

Therefore, the results of the study showed that the spelt grass juice supplementation leads to an increase of phytosterols in the total cholesterol content of the organism. Since it has already been found that phytosterols have a beneficial effect in maintaining the cholesterol balance, and thus of the overall lipoprotein profile, these results suggest a possible beneficial effect of the spelt grass supplementation, observed also through the significant reduction in CRI and Al. Taking the obtained data into the consideration, it has been observed that the spelt juice had a beneficial effect on the prooxidant-antioxidant balance. The anti-inflammatory effect of the spelt supplementation was confirmed by the changes in the hsCRP concentrations. The main limitation of the study is the number of subjects included, so new studies dealing with a similar topic could be of great value. 


\section{ACKNOWLEDGEMENTS}

This research was funded by the Ministry of Education, Science and Technological Development, Republic of Serbia through Grant Agreement with University of Belgrade-Faculty of Pharmacy No: 451-03-9/202114/200161.

\section{REFERENCES}

1. Campbell KG. Spelt: agronomy, genetics, and breeding. Plant Breeding Reviews. 1997;15:187-214.

2. Rösch M. The history of crops and crop weeds in southwestern Germany from the Neolithic period to modern times, as shown by archaeobotanical evidence. Veget Hist Archaeobot. 1998; 7(2):109-25.

3. Bonafaccia G, Galli V, Francisci R, Mair V, Skrabanja V, Kreft I. Characteristics of spelt wheat products and nutritional value of spelt wheat-based bread. Food Chem. 2000;68(4):437-41.

4. Biskup I, Gajcy M, Fecka I. The potential role of selected bioactive compounds from spelt and common wheat in glycemic control. Adv Clin Exp Med. 2017;26(6):1013-9.

5. Skrabanja V, Kovac B, Golob T, Liljeberg Elmståhl HG, Björck IM, Kreft I. Effect of spelt wheat flour and kernel on bread composition and nutritional characteristics. J Agric Food Chem. 2001;49(1):497-500.

6. Ruibal-Mendieta NL, Delacroix DL, Mignolet E, Pycke JM, Marques C, Rozenberg R, et al. Spelt (Triticum aestivum ssp. spelta) as a source of breadmaking flours and bran naturally enriched in oleic acid and minerals but not phytic acid. J Agric Food Chem. 2005;53(7):2751-9.

7. Dinu M, Whittaker A, Pagliai G, Benedettelli S, Sofi F. Ancient wheat species and human health: Biochemical and clinical implications. J Nutr Biochem. 2018;52:1-9.

8. Armentia A, Martín S, Diaz-Perales A, Palacín A, Tordesillas $L$, Herrero $M$, et al. A possible hypoallergenic cereal in wheat food allergy and Baker's asthma. Am J Plant Sci. 2012;3(12):1779-81.

9. Nacionalni vodic dobre klinicke prakse za dijagnostikovanje i lecenje arterijske hipertenzije. Republicka strucna komisija za izradu i implementaciju vodiča dobre kliničke prakse. Agencija za akreditaciju zdravstvenih ustanova, Beograd 2012.

10. Obesity: preventing and managing the global epidemic. Report of a WHO Consultation. WHO. Tec. Rep. Ser. 2000:894.

11. Waist Circumference and Waist-Hip Ratio: Report of a WHO Expert Consultation. WHO. 2008.

12. Friedewald WT, Levy RI, Fredrickson DS. Estimation of the concentration of low-density lipoprotein cholesterol in plasma, without use of the preparative ultracentrifuge. Clin Chem. 1972;18(6):499-502.

13. Castelli WP, Abbott RD, Mcnamara PM. Summary estimates of cholesterol used to predict coronary heart disease. Circulation. 1983;67(4):730-4.

14. Rainwater DL, Andres DW, Ford AL, Lowe F, Blanche PJ, Krauss RM. Production of polyacrylamide gradient gels for the electrophoretic resolution of lipoproteins. J Lipid Res. 1992;33(12):1876-81.

15. Gojkovic T, Vladimirov S, Spasojevic-Kalimanovska V, Zeljkovic A, Vekic J, Arsenijevic J, et al. Preanalytical and analytical challenges in gas chromatographic determination of cholesterol synthesis and absorption markers. Clin Chim Acta. 2018;478:74-81.

16. Kotur-Stevuljevic J, Bogavac-Stanojevic N, JelicIvanovic Z, Stefanovic A, Gojkovic T, Joksic J, et al. Oxidative stress and paraoxonase 1 status in acute ischemic stroke patients. Atherosclerosis. 2015;241(1):192-8.

17. lafelice G, Verardo V, Marconi E, Caboni MF. Characterization of total, free and esterified phytosterols in tetraploid and hexaploid wheats. J Agric Food Chem. 2009;57(6):2267-73.

18. Brown L, Rosner B, Willett WW, Sacks FM. Cholesterollowering effects of dietary fiber: a meta-analysis. Am J Clin Nutr. 1999;69(1):30-42.

19. Seki M, Ishiguro T, Gyohda Y, Ohsato S, Yokota M. Evaluation of the efficacy of coronary risk index, a new scoring system for predicting morbidity and severity of coronary stenosis in patients undergoing coronary angiography. The Journal of Japan Society for Clinical Anesthesia. 1998;18(3):271-6.

20. Kanthe PS, Patil BS, Bagali S, Deshpande A, Shaikh GB, Aithala M. Atherogenic index as a predictor of cardiovascular risk among women with different grades of obesity. Int J Collab Res Intern Med Public Health. 2012;4(10):1767-74.

21. Cohen DE. Balancing cholesterol synthesis and absorption in the gastrointestinal tract. J Clin Lipidol. 2008;2(2):S1-3.

22. Ruibal-Mendieta NL, Rozenberg R, Delacroix DL, Petitjean G, Dekeyser A, Baccelli C, et al. Spelt (Triticum spelta L.) and winter wheat (Triticum aestivum L.) wholemeals have similar sterol profiles, as determined by quantitative liquid chromatography and mass spectrometry analysis. J Agric Food Chem. 2004;52(15):4802-7.

23. Tapiero H, Townsend DM, Tew KD. Phytosterols in the prevention of human pathologies. Biomed Pharmacother. 2003;57(8):321-5.

24. Andersson SW, Skinner J, Ellegård L, Welch AA, Bingham S, Mulligan A, et al. Intake of dietary plant sterols is inversely related to serum cholesterol concentration in men and women in the EPIC Norfolk population: a cross-sectional study. Eur J Clin Nutr. 2004;58(10):137885.

25. Hunter P. The inflammation theory of disease: The growing realization that chronic inflammation is crucial in many diseases opens new avenues for treatment. EMBO Rep. 2012;13(11):968-70.

26. Ben-Arye E, Goldin E, Wengrower D, Stamper A, Kohn $R$, Berry $E$. Wheat grass juice in the treatment of active distal ulcerative colitis: a randomized doubleblind placebo-controlled trial. Scand J Gastroenterol. 2002;37(4):444-9.

27. Subramoniam A, Asha VV, Nair SA, Sasidharan SP, Sureshkumar PK, Rajendran KN, et al. Chlorophyll revisited: Anti-inflammatory activities of chlorophyll a and inhibition of expression of TNF-a gene by the same. Inflammation. 2012;35(3):959-66.

28. Halliwell B. Free radicals, antioxidants, and human disease: curiosity, cause, or consequence? Lancet. 1994;344(8924):721-4.

29. Chauhan M. A pilot study on wheat grass juice for its phytochemical, nutritional and therapeutic potential on chronic diseases. Int J Chem Stud. 2014;2(4):27-34. 
30. Sohal RS, Allen RG, Farmer KJ, Newton RK, Toy PL. Effects of exogenous antioxidants on the levels of endogenous antioxidants, lipid-soluble fluorescent material and life span in the housefly, Musca domestica. Mech Ageing Dev. 1985;31(3):329-36.

\section{Antioksidativna, antiinflamatorna i anti-hiperlipidemična svojstva speltinog soka}

\author{
${ }^{1 *}$ Tamara Antonic, ${ }^{1}$ Aleksandra Stefanovic, \\ 'Tamara Gojkovic, 'Sandra Vladimirov, \\ 'Vesna Spasojevic-Kalimanovska, \\ 1 Jelena Kotur-Stevuljevic, \\ ${ }^{1}$ Natasa Bogavac-Stanojevic, ${ }^{2}$ Branka Bajic \\ ${ }^{1}$ Odeljenje za medicinsku biohemiju, Farmaceutski \\ fakultet, Univerzitet u Beogradu, Beograd, Srbija \\ 2 Specijalisticka internisticka ordinacija Hematologika, \\ Beograd, Srbija
}

\begin{abstract}
Kratak sadržaj
Spelta je žitarica bogata bioaktivnim jedinjenjima - različitim fitohemikalijama, pa se često pominje u kontekstu korisnosti za ljudsko zdravlje. Naš cilj je bio da ispitamo antioksidativna, antiinflamatorna i antihiperlipidemijska svojstva soka od spelte. Dvadeset dobrovoljaca konzumiralo je piče jednom dnevno, rastvarajući jednu dozu u $200 \mathrm{ml}$ mineralne vode, tokom 2 meseca. Svi pojedinci su klinički i biohemijski ispitani. Profili LDL i HDL čestica određeni su elektroforezom na poliakrilamidnom gradijentnom gelu, dok su koncentracije ne-holesterolskih sterola merene gasnom hromatografijom sa plameno-jonizacionim detektorom. C-reaktivni protein visoke osetljivosti (hsCRP) meren je pomoću komercijalno dostupnog testa. Koncentracije
\end{abstract} parametara statusa oksidativnog stresa merene su spektrofotometrijski. lako nisu primećene značajne promene parametara lipidnog profila, vrednosti indeksa koronarnog rizika $(C R I)(p<0.05)$ i aterogenog indeksa $(A I)(p<0.05)$ posle suplementacije su bile niže u poređenju sa vrednostima pre dijetetske intervencije. Nakon analize markera sinteze i apsorpcije holesterola, primetili smo samo značajan porast koncentracije kampesterola ( $p<0.05)$. Štaviše, uočili smo statistički značajan pad koncentracije hsCRP-a kod ispitanika koji su bili suplementirani speltom ( $p<0.001)$. Značajan pad PAB $(p<0.001), A O P P(p<0.05)$ i PON1 $(p<0.001)$ zabeležen je nakon suplementacije. Sa druge strane, vrednosti TAS i koncentracija SH grupa bile su značajno veće nakon dijetetske intervencije ( $p<0.001$, obe). Smatramo da bi suplementacija sokom od speltine trave mogla imati blagotvorne efekte na ukupan lipidni profil, prooksidantno-antioksidativni balans $i$ inflamatorne parametre.

Ključne reči: spelta; sok od speltine trave; neholesterolski steroli; fitosteroli; prooksidantno-antioksidativni balans; inflamacija. 